\title{
DEK Gene
}

National Cancer Institute

\section{Source}

National Cancer Institute. DEK Gene. NCI Thesaurus. Code C24339.

This gene is involved in RNA processing and regulation of chromatin organization. 